\title{
Understanding port choice determinants and port hinterlands: findings from an empirical analysis of Spain
}

Jordi Caballe-Valls (University of Malaga)

Peter W. de Langen (Copenhagen Business School)

Lorena Garcia-Alonso (University of Oviedo)

Jose Angel Vallejo-Pinto (University of Oviedo)

\begin{abstract}
This paper analyses the determinants of port choice of container cargoes from specific hinterland regions, based on an empirical study of Spain. We extend previous work by including novel explanatory variables for the market shares of ports in hinterland regions. Discrete Choice Theory is the methodological approach used here. More specifically, a Nested Logit model is proposed. As potential explanatory variables it includes maritime connectivity to specific overseas regions and intermodal connectivity of the port to specific hinterland regions. The empirical analysis is based on detailed Spanish customs data. The analysis shows that all variables which were hypothesised to influence the market share of a port in a specific hinterland region (i.e., road distance to the hinterland region; maritime distance; maritime connectivity of the port; and intermodal connectivity of the port) indeed significantly influence its market share in a specific hinterland region, with the signs as expected. The findings add to the understanding of port competitiveness in specific regions with three conclusions. First, port hinterlands are relational, in the sense that they depend on the overseas origin or destination of the cargo. Second, the analysis suggests that ports that predominantly handle transhipment cargoes may have a 'transhipment orientation', which is an impediment for reaching hinterland markets. Third, intermodal connectivity is a determinant of the market share of a port in a certain hinterland region.
\end{abstract}

Keywords: port choice, hinterland, Spain 


\section{Introduction and literature review}

The analysis of what hinterlands are served by ports has attracted scholarly attention since the $19^{\text {th }}$ century. Various approaches have been used to advance the understanding of port hinterlands. These include conceptual contributions, such as the widely cited work on 'port regionalisation' (Notteboom \& Rodrigue, 2005; Monios \& Wilmsmeier, 2012); work on 'dry ports' (Roso et al, 2009) and 'extended gates' (see Veenstra et al, 2012), as well as numerous case studies (see for instance Van den Berg \& De Langen, 2011; and Bask et al, 2014) and modelling of port competition and hinterlands (De Borger et al, 2008; Luo et al, 2012). A fourth important stream of research enriches the understanding of port hinterlands through the analysis of port choice. This paper is a part of this fourth research stream. A comprehensive literature review on port choice is provided by Martínez Moya \& Feo Valero (2017). Here, we focus on deepening the understanding of factors that may influence port choice and determine the market shares of ports in certain hinterlands. We focus on three factors that have not been analysed in detail previously: maritime connectivity, intermodal connectivity and transhipment orientation.

We use shipment data (i.e. data that show the origin and destination of container shipments as well as the ports that were used) to test the relevance of factors that influence port choice. This method was selected as detailed shipment data allows precise statistical tests.

The shipment data does not include information about who has made the shipment routing decision. This may be partly because actor roles in port choice are ambiguous, in the sense that often there is no single actor that determines cargo routing. For instance, shippers may outsource the organization of maritime transport to third-party logistics providers but 'de facto' continue to make port choice decisions. Given the absence of data on actors, we do not take a 'behavioural approach': we do not pay attention to potential differences in port choice decisions between different actors, even though De Langen (2007) and Tongzon (2009) do demonstrate differences in port choice decisions between forwarders and shippers.

Regarding port choice factors, the relevance of distance and shipping costs is well established (Luo \& Grigalunas, 2003; Nir et al, 2003; Veldman \& Bückmann, 2003; Malchow \& Kanafani, 2004). Additional variables that have been shown to influence port choice include reliability (Luo \& Grigalunas, 2003) and the inland container transport balance (Veldman \& Bückmann, 2003), as well as indicators of the service quality of a port (Luo \& Grigalunas, 2003; Fan et al, 2010). The latter may for instance include the maximum vessel size that can be handled in the port. In addition to these variables, research has established the relevance of the type of cargo in port choice. Hinterlands are 'commodity specific' in the sense that due to differences in 'values of time' the hinterland of a port is not the same for waste paper and electronics (Malchow \& Kanafani, 2004).

Even though the research on port choice has led to a much better understanding of the issue, and the ability of ports to serve specific hinterlands, there is no established integrated theory that encompasses all previous insights. Instead, the research is in a stage where additional potential variables of port choice are proposed and tested. In this study, we discuss three additional factors that may influence port choice: maritime connectivity, intermodal connectivity and transhipment orientation.

\section{Maritime connectivity}

Maritime connectivity is increasingly analysed with advanced data and data analysis methods (see amongst others UNCTAD, 2018; Ducruet et al, 2010; and Bartholdi, 2016). Wilmsmeier \& Hoffmann (2008) demonstrate the relevance of liner shipping connectivity as determinant of freight rates. While, initially, liner shipping connectivity was developed as a countrywide performance indicator, the bilateral maritime connectivity between countries has later also been added and, in addition, scholars have developed maritime connectivity indicators for specific ports (Bartholdi, 2016).

The relevance of maritime connectivity for understanding port hinterlands has been analysed. Anderson et al (2009) show that shipment time, likely to be good proxy for maritime connectivity, is a determinant of port choice; Halim et al (2016) develop a model which suggests that maritime connectivity is a 
relevant component for location decisions of distribution centres. Wang et al (2016) develop an integrated approach to port connectivity, including both maritime and intermodal connectivity. However, none of these works empirically assesses the relevance of maritime connectivity for port choice decisions to and from specific hinterland locations. This assessment is made in this paper, based on region-specific port connectivity data.

\section{Intermodal connectivity}

Intermodal connectivity is increasingly used in the analysis of port hinterlands. The relevance of intermodalism for the expansion of port hinterlands has been acknowledged for decades (Hayuth, 1982; van Klink \& van den Berg, 1998). More recently, the development of inland ports (sometimes termed dry ports) and their relations with seaports have also been studied (see amongst others Garcia-Alonso et al, 2018; Roso et al, 2009; Van den Berg \& De Langen, 2011; Monios and Wilmsmeier, 2012). Along with the deepening of the understanding of the role of inland ports and intermodal services, empirical work on the relation between port choice and intermodal connections has emerged ${ }^{1}$ (Tavasszy et al, 2011). For instance, Ferrari et al (2011) show, in the case of the Ligurian ports, that intermodal connections influence the size of port hinterlands, while Chen et al (2016) identify infrastructure bottlenecks in the Malaysian intermodal port hinterland connections. However, none of these studies use shipment data to assess the effect of hinterland connectivity on port choice. The inclusion of hinterland connectivity in such a port choice framework is a novelty. Fan et al (2010) develop a model for port choice that includes estimated costs of intermodal rail transport, but does not include the intermodal connections between a hinterland region and the various ports. In this paper, we collect empirical data on the intermodal connectivity of ports, in line with the approach taken by De Langen and Sharypova (2013) and De Langen et al (2017).

\section{Transhipment orientation}

A theoretically novel and empirically unexplored issue introduced in this paper is what we have termed the potential 'transhipment orientation' of a port. The core argument is that a dominant share of transhipment (i.e. moves of a container from one ship to another ${ }^{2}$ ) may be at the expense of services to hinterlands. The advancing hub-and-spoke networks in container shipping have led to the emergence of transhipment hubs. The function of these hubs differs radically from 'traditional ports' in that they function as a critical part of liner shipping networks. This has important consequences. For instance, the 'location logic' of transhipment facilities is completely different: various such facilities are located on small islands (e.g. Malta) with neglectable volumes destined for local and regional hinterlands (Baird, 2006). In addition, shipping lines are more actively involved in terminal operations in such hub ports, through their own terminal facilities or equity stakes in terminals (Notteboom et al, 2017). Finally, the productivity of transhipment terminals differs from gateway terminals (where flows to the hinterland are dominant); productivity measures in moves per crane or per ship are typically higher because of the lower complexity of operations (see Morales Sarriera et al, 2013).

We provide three theoretical reasons for a negative side-effect on hinterland services of transhipment orientation. First, the terminal design of a transhipment terminal is different from the design of a 'gateway terminal' (Monaco et al, 2009). In general, in transhipment terminals, less attention is given to handling hinterland cargo. This may lead to relatively low service levels at hinterland gates. Given the limited hinterland volumes, scale economies are absent, which may have a negative impact on hinterland service levels.

\footnotetext{
${ }^{1}$ In parallel, but less relevant for this paper, the trade-offs between rail and maritime transport have been modelled. Tavasszy et al (2011) found that the potential share of 'all land connections' (such as rail services China-Europe) remains small compared to maritime connections.

2 The emergence of transhipment in hub-and-spoke networks in maritime container transport is well documented (Ducruet and Notteboom, 2012).
} 
Second, transhipment terminals may relatively often be bypassed by container ships. Shipping lines do not always adhere to their published schedules. This leads to the so called 'blank sailings' where either an entire service may be cancelled, or a specific port call may be cancelled ${ }^{3}$. Such blank sailings are not uncommon (see for a news item Mongelluzzo, 2018). Such a port specific blank sailing occurs when the port is congested or ships omit a port to make up for delays. If a port needs to be bypassed, shipping lines may often select a transhipment port because transhipment operations can be shifted to other ports against relatively limited costs compared to shifts of cargo between gateway ports. There are no publicly available data to assess whether or not transhipment ports are more affected by blank sailings; this is a relevant area for further research. We do note that even a fairly limited risk of a blank sailing may be a reason for a shipper to use a different port for (a part of) shipments, especially of time-sensitive goods.

Third, terminals that principally serve hinterlands are commercially active in attracting cargo volumes in these areas. Increasingly, gateway terminals develop hinterland services (see amongst others Franc \& Van der Horst, 2010). Transhipment terminals may have a commercial focus on transhipment cargoes and more limited commercial activities in the hinterland. This also may reduce the volumes to/and from port hinterlands compared to ports without a transhipment orientation.

For these theoretical reasons, in this paper we test whether such a transhipment orientation does have an effect on the market shares of a port in various hinterland regions ${ }^{4}$.

In conclusion, in this paper we aim to expand the understanding of factors that influence port choice and thus port hinterlands. The empirical analysis is done based on data from Spain. The case of Spain has attracted considerable interest over the years, probably due to the fierce competition between a large number of ports in Spain and the interesting feature of Spain as a peninsula, with ports on the North, South and East coast as well as the availability of detailed shipment statistics.

This article is structured as follows: Section 2 details the new factors that may influence port choice and presents the theoretical model and its variables, Section 3 details the empirical analysis based on data for Spain, Section 4 discusses the findings and Section 5 concludes and relates the findings to the emerging literature on strategies of port authorities and terminal operators to improve hinterland access.

\section{Port choice model}

The literature review of port economics, management and policy, by Pallis et al (2010) identifies seven main research themes, one of which is termed 'competition and competitiveness'. This theme includes port choice analysis, a topic of growing interest in the literature, where Discrete Choice Theory stands out as one of the most widely used methodological approaches by researchers. Since the 1980s, Discrete Choice Theory has been increasingly used to analyse the choices made in the transportation field, firstly for passengers and later for goods. Specifically for the port choice analysis, Malchow \& Kanafani (2004) were pioneers in proposing this methodological approach. Lagoudis et al (2017) and Paixao Casaca et al (2010) found that discrete choice modelling (DCM) is applied in around $20 \%$ of the papers published on the topic between 1981 and 2009. More recently, Martínez Moya \& Feo Valero (2017) highlight that most of the articles analysing the port choice topic from the Discrete Choice Theory perspective propose Multinomial Logit Models (MNL).

Following this approach, the probability of port $p$ to be chosen to channel shipment $s$ from province $h$ to the world region $w r$ can be expressed as (1):

\footnotetext{
3 See https://shippingandfreightresource.com/blank-sailing/

${ }^{4}$ These arguments for a negative 'side effect' of a transhipment orientation do not imply focusing on transhipment is 'wrong'. In many transhipment ports, the hinterland cargo potential is limited. Furthermore, success in attracting transhipment will increase maritime connectivity (Arvis et al, 2018), which also makes a port more attractive for hinterland cargoes.
} 


$$
P_{p h w r}=\left(\frac{e^{U_{p h w r}}}{\sum_{p=1}^{p=P} e^{U q h w r}}\right)
$$

Where $P_{p h w r}$ is the probability of choosing port $p$ among all the possible ports, $p=1, \ldots P$, and can be interpreted as the market share of port $p$ with respect to all ports considered.

Using common notation, Port $p$ will be chosen only if the utility derived from its choice satisfies (2):

$$
P_{p, h, w r}=\operatorname{Prob}\left(U_{p, h, w r}>U_{q, h, w r}\right) \forall p \neq q
$$

The utility of a port $p, \mathrm{U}_{\mathrm{p}, \mathrm{h}, \mathrm{wr}}$, is known by the decision-maker but not by the researcher, who must consider it with a random component. Hence, utility has to be broken down into two parts: [i] the observed part (representing the modelled effect of variables considered), $\mathrm{V}_{\mathrm{p}, \mathrm{h}, \mathrm{wr}}$, and [ii] the unobserved part (or error term), $\varepsilon$. Based on the analysis made in the previous section, components of the observed part, based on the attributes considered in this paper, can be obtained from (3):

$$
V_{p, h, w r}=A S C_{p}+\alpha_{1} R D_{p, h}+\alpha_{2} M D_{p, w r}+\alpha_{3} M C_{p, w r}+\alpha_{4} I C_{p, h}
$$

Alternatively, the Alternative Specific Constants (ASC) can be replaced by the port throughput and the transhipment orientation of ports, as shown in (4):

$$
V_{p, h, w r}=\alpha_{1} R D_{p, h}+\alpha_{2} M D_{p, w r}+\alpha_{3} M C_{p, w r}+\alpha_{4} I C_{p, h}+\alpha_{5} P S_{p}+\alpha_{6} T S_{p}
$$

where:

- $R D_{p, h}$ is the road distance between port $p$ and province $h$ (in kilometres);

- $M D_{p, w r}$ is the maritime distance between port $p$ and a world region (in nautical miles);

- $\quad M C_{p, w r}$ is the maritime connectivity of port $p$ with a certain world region, based on vessel calls and their capacity;

- $\quad I C_{p, h}$ is a dummy regarding the existence of intermodal connectivity between port $p$ and province $h$;

- $\quad P S_{p}$ is the total container throughput of the port, based on the idea that there are scale economies in port operations, leading to higher productivity and/or lower costs in larger ports;

- $T S_{p}$ reflects the transhipment orientation, which based on the theoretical arguments provided above is added for ports with high transhipment to test whether this negatively affects their shares in hinterland regions.

As discussed previously, the majority of Discrete Choice models in ports have employed Multinomial Logit Models (MNL). The main advantage of the MNL is their simplicity. It is assumed that the error term is independently and identically distributed, and follows the Gumbel distribution (see McFadden, 1973). This assumption implies that the introduction (or improvement) of any additional alternative will have the same impact on the probability of the rest to be chosen, which is too restrictive. The most straightforward way to overcome that restriction is by applying a Nested Logit model (NL) (see Anderson et al, 2009; Veldman et al, 2013; or Cantillo et al, 2018). The NL allows us to relax the assumption of independence from irrelevant alternatives (IIA). To solve this problem, the alternatives (ports) are grouped in nests with some degree of similarity among them (e.g. to be located on the same coastline), in such a way that the hypothesis of IIA remains valid within each nest (a group of ports on the Atlantic coast and a group for the Mediterranean coast). We also deploy this approach in our empirical analysis.

To test the significance of the new variables, information is required on the market shares of ports in specific hinterland regions, and with regard to specific overseas destination areas. The estimation of this data as well as the results of the statistical tests are addressed in the next section. 


\section{Empirical analysis based on data for Spain}

The case study we address focuses on Spanish containerised exports channelled by sea through the main Spanish ports. Data about flows was obtained from the Foreign Trade Statistics of the Customs and Excise Duties Department of the Spanish Tax Agency. They are freely available and provide information about exports composition and volume (both in Euros and tonnes), their origin (at the level of Spain's provinces) and the country of destination. As Escamilla-Navarro et al (2010) pointed out, this data source is particularly reliable for the analysis of extra-EU maritime traffic ${ }^{5}$ and useful in delimiting the hinterland of ports. The data has already been successfully used for this purpose in previous port hinterland analyses, most recently in Moura et al $(2017 ; 2018)^{6}$.

The ports usually considered when analysing port choice questions in Spain are the main four ports (islands excluded): Algeciras, Barcelona, Bilbao and Valencia. This is because these are the only Spanish ports competing for a contestable hinterland. The rest only attract traffic from their closest territories, and their inclusion could distort our results (for instance, the role of distance). Nevertheless, we wanted to expand the analysis and include more ports in the study. Based on their container traffic, the ports of Castellón and Vigo were the most relevant potential additions. Vigo was included in the analysis as it is located far away from the rest. Hence, it is expected not to distort the results and to be of interest. The port of Castellón was excluded because of its proximity to Valencia and the mainly captive local hinterland it serves. The Portuguese ports were also excluded in the analysis because the Spanish traffic channelled through them is insignificant (see Santos \& Soares, 2017). Based on these considerations, we constructed a database that divides all maritime shipments according to departure and destination region. The number of observations was determined by the number of provinces in Spain $\left(47^{7}\right)$; by the number of ports considered (five); and by the number of destination country regions (four), essentially covering the areas north, east, south, and west of Spain. This led to 940 observations for one year.

The road distance between port $p$ and hinterland $h$ in kilometres $\left(R D_{p, h}\right)$ was calculated for all the province-port pairs by using Google maps. The distance was calculated from each port to the provincial capital city, where the main density of population and economic activity is concentrated. When the port is located in the same capital city, the internal distance of provinces was considered proportional to the square root of their area (in $\mathrm{km}^{2}$ ) following Garcia-Alonso \& Marquez (2017), as can be seen in (5)

$$
d_{i i}=0.66 \sqrt{\frac{\operatorname{area}_{h}}{\Pi}}
$$

The maritime distance between port $p$ and a world region in nautical miles $\left(M D_{p, w r}\right)$ was calculated by taking one reference port ${ }^{9}$ and include this distance, calculated with the website www.sea-distances.org. Table 1 shows the distances in nautical miles from the five Spanish ports to the four world regions.

\footnotetext{
${ }^{5}$ Data about the flows within the EU come from Instrastat Declarations, presented monthly and only for transactions surpassing a threshold. Additionally, the procedure also allows several consignments to be grouped, thus these flows were excluded from the analysis.

${ }^{6}$ In addition to the Spanish case, different articles can be found using custom data to analyze this topic in other countries. Among the most recent are Cantillo et al (2018) (Dirección de Impuestos y Aduanas Nacionales de Colombia) and Brodzicki \& Uminski (2018) (Oficina Central de Estadística y Cámara de Aduanas de Polonia).

7 The provinces Ceuta, Melilla, Canary Islands, and Balearic Islands, were excluded as they cannot be hinterlands of the five mentioned ports.

${ }^{8}$ See Crozet (2004), Head \& Mayer (2000) or Nitsch (2000) for a detailed discussion.

${ }^{9}$ Reference ports regarding the four world regions are Port Said for East Med \& Asia, Amsterdam for North \& Central Europe, Houston for North America and Abidjan for West Africa and South America.
} 
Table 1. Distances in nautical miles from Spanish ports to four main world regions

\begin{tabular}{llllll}
\hline Spanish port & $\begin{array}{r}\text { East } \\
\text { Asia }\end{array}$ & Med & $\begin{array}{c}\text { and } \begin{array}{l}\text { North } \\
\text { Central Europe }\end{array} \\
\text { and }\end{array}$ & $\begin{array}{l}\text { North } \\
\text { Central America } \\
\text { and }\end{array}$ & $\begin{array}{l}\text { West } \\
\text { and } \begin{array}{c}\text { Africa } \\
\text { South } \\
\text { America }\end{array}\end{array}$ \\
Barcelona & 1588 & 1904 & 5283 & 3168 \\
Algeciras & 1915 & 1393 & 4772 & 2657 \\
Valencia & 1669 & 1776 & 5155 & 3040 \\
Vigo & 2430 & 898 & 4553 & 2895 \\
Bilbao & 2774 & 799 & 4786 & 3230 \\
\hline
\end{tabular}

Maritime connectivity of port $p$ with a certain world region $\left(M C_{p, w r}\right)$ is expressed as the sum of the vessel capacities of ships that call in port $p$ and also in the world region in question, ${ }^{10}$ based on data drawing on Lloyd's List ship movements (see Lam \& Yap, 2008; Mohamed-Chérif \& Ducruet, 2016; and Arvis et al, 2018 for papers with a similar approach). In our model, $M C_{p, w r}$ has been normalised per port: the percentage that each port represents in each zone has been calculated.

The dummy regarding the existence of intermodal connectivity between port $p$ and hinterland $h\left(I C_{p, h}\right)$ is calculated based on data on intermodal connections, in a matrix of 47 regions and five ports, and has the value 1 if there is an intermodal connection and 0 if this is not the case. In this approach, the value of intermodal connectivity is 1 if there is a service to the origin/destination province. Only rail transport increases intermodal connectivity in Spain, as the country has no inland waterways for containers. In this approach, the value of intermodal connectivity is only 1 if there is a service to the origin/destination province. We acknowledge that this method is imperfect, because it does not consider link quality and because one could argue that a province is also intermodally connected when there is a service from a neighbouring region to a port. However, given the complexity of expressing link quality (see De Langen et al, 2016, for an attempt to quantify link quality of shipping connections) as well as accounting for indirect intermodal connections, we have not addressed this issue in this paper.

The port size $\left(P S_{p}\right)$ is the variable for the total container throughput of the port, based on the idea that there are scale economies in port operations, leading to higher productivity and/or lower costs in larger ports. This information was provided by the Spanish national entity governing ports (Puertos del Estado, 2018).

Transhipment $\left(T S_{p}\right)$ is a variable that reflects the transhipment orientation. As detailed in Section 2, the theoretical logic is broadly that if both shipping lines and the terminal operator are focused on transhipment operations, this is at the expense of the quality of services for containers to/from the hinterland. In Spain, this leads to a dummy, which is 1 for Algeciras and Valencia (with a transhipment percentage of $92 \%$ and $61 \%$ of the total container volume handled in 2015, respectively, thus higher than a cut-off level of 50\%) and 0 for the other Spanish ports, as these do not have high shares of transhipment. Maritime Connectivity was based on data from ship movements from Lloyd's List Intelligence $^{11}$ (see Ducruet, 2015, 2017, and World Bank for studies based on the same data).

\footnotetext{
${ }^{10}$ This approach is needed as unlike countries, where maritime connectivity data is made publicly available by UNCTAD, for ports there is no indicator of connectivity that is publicly available.

${ }^{11}$ The data were kindly provided by Cesar Ducruet in the context of the joint World Bank publication (Arvis et al, 2018). 


\section{Results and discussion of the findings}

The model results are shown in Table 2 and Table 3. On the one hand, Table 2 shows the two specifications of the model, (3) and (4). Both have a similar adjustment, but we consider model (4) to fit better than (3). Although (4) is slightly weaker in terms of log-likelihood, all the variables are significant in this specification and its hit rate is higher. Table 3 shows a so-called Confusion Matrix, used to describe the performance of the models by comparing their results with the already known port choice carried out. In both specifications, (3) and (4), the best fit is for Vigo, and the worst for Valencia. This is due to the fact that the hinterland of Vigo is mainly captive and limited to a smaller number of provinces, while Valencia is the port with largest hinterland reach in Spain (see Garcia-Alonso et al, 2016, and Grecco et al, 2017), followed by Barcelona (the second worst fit in terms of the confusion matrix). 
Table 2. Results of analysis

\begin{tabular}{|c|c|c|c|c|c|c|}
\hline Coefficients & Estimate (3) & z-value & $\operatorname{Pr}(>|z|)$ & Estimate (4) & z-value & $\operatorname{Pr}(>|z|)$ \\
\hline $\mathrm{ASC}_{\text {Valencia }}$ & -------- & --------- & & & & \\
\hline $\mathrm{ASC}_{\text {Algeciras }}$ & -0.024 & 0.635 & 0.526 & & & \\
\hline $\mathrm{ASC}_{\text {Barcelona }}$ & -0.172 & -6.693 & 0.000 & & & \\
\hline $\mathrm{ASC}_{\text {Bilbao }}$ & -1.352 & -28.815 & 0.000 & & & \\
\hline $\mathrm{ASC}_{\text {Vigo }}$ & -1.498 & -14.796 & 0.000 & & & \\
\hline $\mathrm{RD}_{\mathrm{p}, \mathrm{h}}$ & -0.005 & -53.649 & 0.000 & -0.005 & -57.537 & 0.000 \\
\hline $\mathrm{MD}_{\mathrm{p}, \mathrm{wr}}$ & -0.0004 & -5.6 & 0.000 & -0.0004 & -5.418 & 0.000 \\
\hline $\mathrm{MC}_{\mathrm{p}, \mathrm{wr}}$ & 2.083 & 6.594 & 0.000 & 2.388 & 8.222 & 0.000 \\
\hline $\mathrm{IC}_{\mathrm{p}, \mathrm{h}}$ & 0.258 & 6.196 & 0.000 & 0.285 & 7.188 & 0.000 \\
\hline $\mathrm{PS}_{\mathrm{p}}$ & & & & 0.001 & -19.309 & 0.000 \\
\hline $\mathrm{TS}_{\mathrm{p}}$ & & & & -2.293 & 23.029 & 0.000 \\
\hline Iv: Atl & 0.699 & 17.339 & 0.000 & 0.721 & 22.191 & 0.000 \\
\hline Iv: Med & 0.832 & 46.265 & 0.000 & 0.858 & 51.289 & 0.000 \\
\hline Log-Likelihood & -11779 & & & -11788 & & \\
\hline Hit Ratio & $81.494 \%$ & & & $81.65 \%$ & & \\
\hline
\end{tabular}

Table 3. Confusion Matrix

\begin{tabular}{|l|r|r|r|r|r|r|r|r|r|r|}
\hline & \multicolumn{2}{|c|}{ Algeciras } & \multicolumn{2}{c|}{ Barcelona } & \multicolumn{2}{|c|}{ Bilbao } & \multicolumn{2}{c|}{ Valencia } & \multicolumn{2}{|c|}{ Vigo } \\
\hline $\mathrm{V}_{\text {phwr }}$ & $(3)$ & $(4)$ & $(3)$ & $(4)$ & $(3)$ & $(4)$ & $(3)$ & $(4)$ & $(3)$ & $(4)$ \\
\hline Algeciras & $\mathbf{8 8 3}$ & $\mathbf{8 8 3}$ & 115 & 115 & 67 & 72 & 381 & 376 & 8 & 8 \\
\hline Barcelona & 63 & 63 & $\mathbf{5 0 2 4}$ & $\mathbf{5 0 2 4}$ & 363 & 363 & 1022 & 1022 & 29 & 29 \\
\hline Bilbao & 15 & 15 & 92 & 92 & $\mathbf{9 7 1}$ & $\mathbf{1 0 0 8}$ & 269 & 232 & 4 & 4 \\
\hline Valencia & 125 & 125 & 402 & 402 & 370 & 378 & $\mathbf{7 5 0 2}$ & $\mathbf{7 4 9 4}$ & 41 & 41 \\
\hline Vigo & 0 & 0 & 11 & 11 & 18 & 18 & 33 & 33 & $\mathbf{7 1 6}$ & $\mathbf{7 1 6}$ \\
\hline
\end{tabular}

As can be seen in Table 2, all variables are significant with the expected sign. Maritime connectivity and transhipment orientation have the strongest influence on port choice. These results support the emphasis of policy makers and port developers on maritime and intermodal connectivity, showing that both types of connectivity are important when operators choose a port. The main findings of the study are summarized below: 
- Maritime distance significantly affects the market share of a port for a specific world region, which shows that hinterlands are 'relational'. For instance, Valencia has a higher share (across regions) of cargoes to and from Asia, while Bilbao has a higher market share of cargoes to and from Northern Europe. This shows the hinterland of a port is 'relational' in the sense that it depends of the overseas origin/destination of the cargo. For instance, the hinterland of the port complex of Los Angeles \& Long Beach covers, say, as much as $60 \%$ of the whole US territory for goods to/from North East Asia, while it may be as limited as $15 \%$ of the US territory for goods to/from Europe and Asia.

- Maritime connectivity also significantly and positively influences the market shares of ports in hinterland. This is an important insight, as maritime connectivity depends both on the port and the world region, whereas container throughput depends only on the port.

- Intermodal connectivity, that is, intermodal services, also positively influences the market share of a port in a hinterland region.

- Port size is also significant, and represents the positive effect of scale economies in ports.

- Road distance has a significant negative effect on the market share of a port. This is in line with previous studies.

- The dummy variable -transhipment- is also significant, with the expected negative sign. This is an important finding as it suggests that a high share of transhipment volume may lead to an orientation on transhipment, with adverse effects on hinterland flows.

This paper shows there are no clear 'boundaries' between the hinterlands of different ports, various ports have market shares in 'contestable hinterlands', and hinterlands differ per overseas destination. Nevertheless, the findings provide a basis for assessing regions where a port either has a significant market share or can aspire to develop such a market share, based on current ${ }^{12}$ maritime connectivity and hinterland transport infrastructure (Ferrari et al, 2011 have developed a model looking at hinterland in isolation), based on a utility function that shows the utility for port users of importing/exporting through port $p$ to/from hinterland $h$.

\section{Conclusions and further research}

This paper tested a model, with novel variables, for the market shares of a port in a certain hinterland. The empirical analysis, based on detailed shipment data from Spain, confirmed the expected effect of all tested variables: road distance (-), maritime distance $(-)$, maritime connectivity $(+)$, intermodal connectivity $(+)$, port size $(+)$ and 'transhipment orientation' $(-)$.

Three limitations of the study need to be acknowledged: first, the method to calculate intermodal connectivity is imperfect and could be improved by adding a way to assess the quality of hinterland links, as well as the 'indirect intermodal connectivity' of a province, through the availability of intermodal connections in a neighbouring province. Second, this paper suggests the detrimental effects of a 'transhipment orientation'. This is a relevant contribution, but calls for additional analysis as the current method to treat transhipment through a dummy is imperfect, as it requires a cut-off value, which in this paper was arbitrarily set at $50 \%$. Furthermore, a 'transhipment orientation' may be better regarded as a risk for transhipment ports, rather than as a given. There certainly is scope for 'agency' by the port community in a transhipment port to improve services to the hinterland. Third, like in the previous work on port choice, the imperfect data availability prevents an all-encompassing test on port choice, where all potentially relevant variables are included. For instance, in this paper, data on the shipment type (e.g. commodity group or shipment value) was not included as a potential determinant

\footnotetext{
12 Thus, this method does not take into account potential improvements of hinterlands through investments in infrastructure. This can generate controversy with ports that generally have too expanded a notion of the hinterlands they (can) serve.
} 
of port choice even though it was found to be relevant in previous studies (e.g. Malchow \& Kanafani, 2004).

These findings are relevant for the emerging literature on strategies of port authorities and terminal operators to improve hinterland access. The model results show that, from the variables mentioned above, maritime connectivity has the strongest effect on the market share of a port in the hinterland. Thus, a strategy by both the port authority and the wider port community to explicitly pursue increases in maritime connectivity may be worth considering. One element of such a strategy may be pricing (see Van den Berg et al, 2017, who suggest a pricing strategy to increase connectivity). More research on potential tools to increase maritime connectivity and their effectiveness is warranted.

A second variable that affects the market share of a port and can be influenced by a port authority and other actors in the port community is intermodal connectivity. Thus, strategies of both the port authority and terminal operators to actively improve such connectivity may be sensible, and indeed have been developed (see amongst others Van den Berg \& De Langen, 2011; Monios \& Wilmsmeier, 2012; and Shi \& Li, 2016).

The third variable is the transhipment orientation. This variable also has a strong influence on the market shares of a port. Given the fact that this concept is novel, both conceptually and empirically, more research is required to establish whether there indeed is a trade-off between a hinterland and a transhipment orientation, or alternatively, whether an 'and-and' strategy can be pursued. One relevant issue is whether port authorities, in ports with predominantly transhipment traffic, can effectively include hinterland service levels in concession granting procedures. For instance, the inclusion of hinterland services in the assessment (scoring) of proposals may be an option. Alternatively, minimum hinterland service levels (e.g. average turnaround times of trucks) may be included in concession contracts. This is a relevant topic in the emerging stream of research on concessions in ports (see Theys et al, 2010, and Ferrari et al, 2018).

\section{Acknowledgements}

Garcia-Alonso acknowledges the financial support provided by the Government of Spain under the project PGC2018-097965-B-I00. 


\section{References}

Anderson, C. M., Opaluch, J. J. and Grigalunas, T. A. 2009: The demand for import services at US container ports. Maritime Economics and Logistics 11: 156-185.

Arvis, J. F., Vesin, V., Carruthers, R., Ducruet, C., \& de Langen, P. (2018). Maritime Networks, Port Efficiency, and Hinterland Connectivity in the Mediterranean. International Development in Focus. Washington, DC: World Bank.

Baird, A. J. (2006). Optimising the container transhipment hub location in northern Europe. Journal of transport geography, 14(3), 195-214.

Bartholdi, J. J. (2016) 'A new connectivity index for container ports', Maritime Economics \& Logistics. Palgrave Macmillan, 18(3), pp. 231-249. doi: 10.1057/mel.2016.5.

Bask, A., Roso, V., Andersson, D., \& Hämäläinen, E. (2014). Development of seaport-dry port dyads: two cases from Northern Europe. Journal of Transport Geography, 39, 85-95.

Brodzicki, T. and Uminski, S. (2018). A gravity panel data analysis of foreign trade by regions: the role of metropolises and history. Reg. Stud. 52, 261-273.

https://doi.org/10.1080/00343404.2017.1296123

Cantillo, J., Cantillo, V. and Arellana, J. (2018) 'Modelling with joint choice of ports and countries of origin and destination: application to Colombian ports', Maritime Policy \& Management. Taylor \& Francis, pp. 1-19.

Chen, S.-L., Jeevan, J. and Cahoon, S. (2016) 'Malaysian Container Seaport-Hinterland Connectivity: Status, Challenges and Strategies', The Asian Journal of Shipping and Logistics, 32(3), pp. 127-138. doi: https://doi.org/10.1016/j.ajs1.2016.09.001.

Crozet, M. (2004). Do migrants follow market potentials? An estimation of a new economic geography model. J. Econ. Geogr. 4, 439-458.

De Borger, B., Proost, S., \& Van Dender, K. (2008). Private port pricing and public investment in port and hinterland capacity. Journal of Transport Economics and Policy (JTEP), 42(3), 527-561.

De Langen, P. W. (2007) 'Port competition and selection in contestable hinterlands; the case of Austria'. European Journal of Transport and Infrastructure Research, 7(1), 1-14.

De Langen, P. W. and Sharypova, K. (2013) 'Intermodal connectivity as a port performance indicator', Research in Transportation Business \& Management, 8, pp. 97-102. doi: https://doi.org/10.1016/j.rtbm.2013.06.003.

De Langen, P. W., Udenio, M., Fransoo, J. C., \& Helminen, R. (2016). Port connectivity indices: an application to European RoRo shipping. Journal of Shipping and Trade, 1(1), 6.

De Langen, P. W., Lases Figueroa, D.M., van Donselaar, K.H. and Bozuwa, J. (2017) 'Intermodal connectivity in Europe, an empirical exploration', Research in Transportation Business \& Management, 23, pp. 3-11. doi: https://doi.org/10.1016/j.rtbm.2017.02.003.

Ducruet, C., Lee, S.-W. and Ng, A. K. Y. (2010) 'Centrality and vulnerability in liner shipping networks: revisiting the Northeast Asian port hierarchy', Maritime Policy \& Management. Routledge, 37(1), pp. 17-36. doi: 10.1080/03088830903461175.

Ducret, C. and Notteboom, T. (2012) 'The worldwide maritime network of container shipping: spatial structure and regional dynamics', Global Networks, 12(3), pp. 395-423. doi: doi:10.1111/j.1471- 
0374.2011.00355.x.

Ducruet, C. (2015) Maritime networks: spatial structures and time dynamics. Routledge.

Ducruet, C. (2017) 'Multilayer dynamics of complex spatial networks: The case of global maritime flows (1977-2008)', Journal of Transport Geography. Elsevier, 60, pp. 47-58.

Escamilla-Navarro, L., García Menéndez, L., Pérez-García, E., 2010. Integration of foreign trade and maritime transport statistics in Spain. Marit. Policy Manag. 37, 347-375.

https://doi.org/10.1080/03088839.2010.486641Fan, L., Wilson, W. W. and Tolliver, D. (2010)

'Optimal network flows for containerized imports to the United States', Transportation Research Part

E: Logistics and Transportation Review, 46(5), pp. 735-749. doi:

https://doi.org/10.1016/j.tre.2010.01.001.

Ferrari, C., Parola, F. and Gattorna, E. (2011) 'Measuring the quality of port hinterland accessibility :

The Ligurian case', Transport Policy. Elsevier, 18(2), pp. 382-391. doi:

10.1016/j.tranpol.2010.11.002.

Ferrari, C., Puliafito, P. P., \& Tei, A. (2018). Port Terminal Concessions: Towards a Dynamic Concession Fee. Journal of Transport Economics and Policy (JTEP), 52(2), 137-156.

Franc, P. and Van der Horst, M. (2010) 'Understanding hinterland service integration by shipping lines and terminal operators: a theoretical and empirical analysis', Journal of Transport Geography, 18(4), pp. 557-566. doi: https://doi.org/10.1016/j.jtrangeo.2010.03.004.

Garcia-Alonso, L., Martinez-Pardo, A. and Vallejo-Pinto, J. A. (2016) 'Analysis of the spatial development of the hinterland of ports: a case study', International Journal of Shipping and Transport Logistics, 8(2), p. 111. doi: 10.1504/IJSTL.2016.075007.

Garcia-Alonso, L. and Marquez, M.A. (2017). The role of the market potential in the port choice process: A case study. Int. J. Transp. Econ. 44. https://doi.org/10.19272/201706703002

Garcia-Alonso, L, Monios, J., Vallejo-Pinto, J. A. (2018) 'Port competition through hinterland accessibility: the case of Spain. Maritime Economics and Logistics (forthcoming)'.

Grecco, T., Garcia-Alonso, L., and Salas-Olmedo, M. (2017) 'Delimiting the scope of the hinterland of ports : Proposal and case study', Journal of Transport Geography. Elsevier, 65(September), pp. 35-43. doi: 10.1016/j.jtrangeo.2017.09.012.

Halim, R. A., Kwakkel, J. H. and Tavasszy, L. A. (2016) 'A strategic model of port-hinterland freight distribution networks', Transportation Research Part E. Elsevier Ltd, 95, pp. 368-384. doi: 10.1016/j.tre.2016.05.014.

Hayuth, Y. (1982) 'Intermodal Transportation and the Hinderland Concept', Tijdschrift voor Economische en Sociale Geografie, 73(1), pp. 13-21. doi: doi:10.1111/j.1467-9663.1982.tb00947.x.

Head, K. and Mayer, T. (2000). Non-Europe: The magnitude and causes of market fragmentation in the EU. Rev. World Econ. Weltwirtschaftliches Arch. 136, 284-314.

Lagoudis, I. N., Theotokas, I. and Broumas, D. (2017) 'A literature review of port competition research', International Journal of Shipping and Transport Logistics. Inderscience Publishers, 9(6), pp. 724-762. doi: 10.1504/IJSTL.2017.086940.

Lam, J. S. L., \& Yap, W. Y. (2008). Competition for transhipment containers by major ports in Southeast Asia: slot capacity analysis. Maritime Policy \& Management, 35(1), 89-101. 
Luo, M. and Grigalunas, T. A. (2003) 'A spatial-economic multimodal transportation simulation model for US coastal container ports', Maritime Economics and Logistics, 5(2), pp. 158-178. doi: 10.1057/palgrave.mel.9100067.

Luo, M., Liu, L., \& Gao, F. (2012). Post-entry container port capacity expansion. Transportation Research Part B: Methodological, 46(1), 120-138.

Malchow, M. B. and Kanafani, A. (2004) 'A disaggregate analysis of port selection', 40, pp. 317-337. doi: $10.1016 /$ j.tre.2003.05.001.

Martínez Moya, J. and Feo Valero, M. (2017) 'Port choice in container market: a literature review', Transport Reviews, 37(3), pp. 300-321. doi: 10.1080/01441647.2016.1231233.

McFadden, D. (1973) 'Conditional logit analysis of qualitative choice behavior'. Institute of Urban and Regional Development, University of California Oakland.

Mohamed-Chérif, F., \& Ducruet, C. (2016). Regional integration and maritime connectivity across the Maghreb seaport system. Journal of Transport Geography, 51, 280-293.

Monaco, M. F., Moccia, L. and Sammarra, M. (2009) 'Operations Research for the management of a transhipment container terminal: The Gioia Tauro case', Maritime Economics \& Logistics, 11(1), pp. 7-35. doi: 10.1057/mel.2008.21.

Mongelluzzo, B. (2018) More blank sailings spell volatility for trans-Pacific, Journal of Commerce, available at https://www.joc.com/maritime-news/trade-lanes/trans-pacific/more-blank-sailings-spellvolatility-trans-pac_20181017.html

Monios, J. and Wilmsmeier, G. (2012) 'Giving a direction to port regionalisation', Transportation Research Part A: Policy and Practice, 46(10), pp. 1551-1561. doi:

https://doi.org/10.1016/j.tra.2012.07.008.

Morales Sarriera, J., Serebrisky, T., Briceño-Garmendia, C., \& Schwartz, J. (2013). Benchmarking Container Port Technical Efficiency in Latin America and the Caribbean (No. IDB-WP-474). IDB Working Paper Series.

Moura, T.G.Z., Garcia-Alonso, L., Salas-Olmedo, M.H. (2017). Delimiting the scope of the hinterland of ports: Proposal and case study. J. Transp. Geogr. 65, 35-43.

https://doi.org/https://doi.org/10.1016/j.jtrangeo.2017.09.012

Moura, T.G.Z., Garcia-Alonso, L. and Del Rosal, I. (2018). Influence of the geographical pattern of foreign trade on the inland distribution of maritime traffic. J. Transp. Geogr. 72, 191-200. https://doi.org/10.1016/j.jtrangeo.2018.09.008

Nir, A.-S., Lin, K. and Liang, G.-S. (2003) 'Port choice behaviour--from the perspective of the shipper', Maritime Policy \& Management. Routledge, 30(2), pp. 165-173. doi: 10.1080/0308883032000069262.

Nitsch, V. (2000). National borders and international trade: Evidence from the European Union. Can. J. Econ. 33, 1091-1105.

Notteboom, T. E., \& Rodrigue, J. P. (2005). Port regionalization: towards a new phase in port development. Maritime Policy \& Management, 32(3), 297-313.

Notteboom, T. E., Parola, F., Satta, G., \& Pallis, A. A. (2017). The relationship between port choice and terminal involvement of alliance members in container shipping. Journal of Transport Geography, 
$64,158-173$.

Paixao Casaca, A. C., Carvalho, S. and Oliveira, M. (2010) 'Port choice in the European short sea shipping market: the view of point of port authorities', in IAME 2010 Annual Conference Proceedings, pp. 7-9.

Pallis, A. A., Vitsounis, T. K., \& De Langen, P. W. (2010). Port economics, policy and management: Review of an emerging research field. Transport Reviews, 30(1), 115-161.

Puertos del Estado (2018) port statistics available at http://www.puertos.es/es-es/estadisticas, accessed December 2018.

Roso, V., Woxenius, J. and Lumsden, K. (2009) 'The dry port concept: connecting container seaports with the hinterland', Journal of Transport Geography, 17(5), pp. 338-345. doi: https://doi.org/10.1016/j.jtrangeo.2008.10.008.

Santos, T.A. and Soares, C.G. (2017). Development dynamics of the Portuguese range as a multi-port gateway system. J. Transp. Geogr. 60, 178-188.

https://doi.org/http://dx.doi.org/10.1016/j.jtrangeo.2017.03.003

Shi, X., \& Li, H. (2016). Developing the port hinterland: Different perspectives and their application to Shenzhen Port, China. Research in Transportation Business \& Management, 19, 42-50.

Tavasszy, L., Minderhoud, M., Perrin, J.F. and Notteboom, T. (2011) 'A strategic network choice model for global container flows: specification, estimation and application', Journal of Transport Geography. Elsevier, 19(6), pp. 1163-1172.

Theys, C., Notteboom, T. E., Pallis, A. A., \& De Langen, P. W. (2010). The economics behind the awarding of terminals in seaports: Towards a research agenda. Research in Transportation Economics, 27(1), 37-50.

Tongzon, J. L. (2009) 'Port choice and freight forwarders q', Transportation Research Part E. Elsevier Ltd, 45(1), pp. 186-195. doi: 10.1016/j.tre.2008.02.004.

UNCTAD (2018) Liner Shipping Connectivity Data, available at http://unctadstat.unctad.org/wds/TableViewer/tableView.aspx?ReportId=92, accessed December 2018.

Van den Berg, R., \& De Langen, P. W. (2011). Hinterland strategies of port authorities: A case study of the port of Barcelona. Research in Transportation Economics, 33(1), 6-14.

Van Den Berg, R., De Langen, P. W., \& Van Zuijlen, P. C. (2017). Revisiting port pricing; a proposal for seven port pricing principles. WMU Journal of Maritime Affairs, 16(3), 421-438.

Van Klink, H. A. and van den Berg, G. C. (1998) 'Gateways and intermodalism', Journal of Transport Geography, 6(1), pp. 1-9. doi: https://doi.org/10.1016/S0966-6923(97)00035-5.

Veenstra, A., Zuidwijk, R., \& Van Asperen, E. (2012). The extended gate concept for container terminals: Expanding the notion of dry ports. Maritime Economics \& Logistics, 14(1), 14-32.

Veldman, S. J. and Bückmann, E. H. (2003) 'A Model on Container Port Competition: An Application for the West European Container Hub-Ports', Maritime Economics \& Logistics, 5(1), pp. 3-22. doi: 10.1057/palgrave.mel.9100058.

Veldman, S., Garcia-Alonso, L. and Vallejo-Pinto, J. Á. (2013) 'A port choice model with logit models: a case study for the Spanish container trade', International Journal of Shipping and 
Transport Logistics. Inderscience Publishers Ltd, 5(4-5), pp. 373-389.

Wang, G. W. Y., Zeng, Q., Li, K. and Yang, J. (2016) 'Port connectivity in a logistic network: The case of Bohai Bay, China', Transportation Research Part E: Logistics and Transportation Review, 95, pp. 341-354. doi: https://doi.org/10.1016/j.tre.2016.04.009.

Wilmsmeier, G. and Hoffmann, J. (2008) 'Liner Shipping Connectivity and Port Infrastructure as Determinants of Freight Rates in the Caribbean', Maritime Economics \& Logistics, 10(1), pp. 130151. doi: 10.1057/palgrave.mel.9100195. 